Journal of Southeast Asian

\title{
Special Issue Editor's Introduction: 50 Years of Model Minority Stereotype Research
}

Nicholas Daniel Hartlep

Metropolitan State University, nicholas.hartlep@metrostate.edu

50 Years of Model Minority Stereotype Research

Dr. Nicholas D. Hartlep

Metropolitan State University

Follow this and additional works at: https://docs.lib.purdue.edu/jsaaea

Part of the Bilingual, Multilingual, and Multicultural Education Commons, and the Higher Education Commons

\section{Recommended Citation}

Hartlep, Nicholas Daniel (2017) "Special Issue Editor's Introduction: 50 Years of Model Minority

Stereotype Research," Journal of Southeast Asian American Education and Advancement: Vol. 12 : Iss. 2, Article 5.

DOI: $10.7771 / 2153-8999.1160$

Available at: https://docs.lib.purdue.edu/jsaaea/vol12/iss2/5

This document has been made available through Purdue e-Pubs, a service of the Purdue University Libraries. Please contact epubs@purdue.edu for additional information.

This is an Open Access journal. This means that it uses a funding model that does not charge readers or their institutions for access. Readers may freely read, download, copy, distribute, print, search, or link to the full texts of articles. This journal is covered under the CC BY-NC-ND license. 


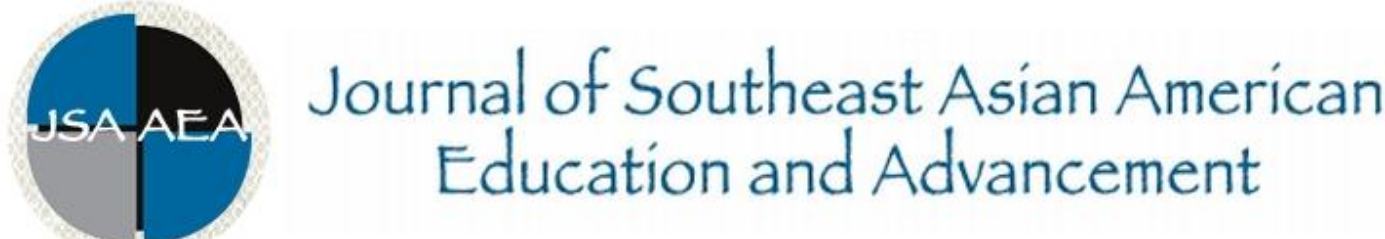

Vol. 12 Iss. 2 Special Issue (2017) $\quad$ www.JSAAEA.org

Special Issue: 50 Years of Model Minority Stereotype Research

\author{
Nicholas D. Hartlep \\ Metropolitan State University
}

\section{Special Issue Editor's Introduction}

Since 1966, William Petersen's New York Times Magazine article "Success Story: Japanese American Style" has been cited as the scholarly progenitor of the model minority stereotype. ${ }^{1}$ However, as Wu (2016) points out in her book The Color of Success: Asian Americans and the Origins of Model Minority, "The field [Asian American Studies] ironically has crafted its own mythology of the model minority by insisting that the stereotype originated as an imposition on Asian Americans by others, particularly a handful of mainline journalists and social scientists" (p. 255). Wu's historical analysis is informative to my research, and like her, I've devoted a considerable amount of my time to studying the model minority stereotype. My understanding is that my book The Model Minority Stereotype: Demystifying Asian American Success is the only published annotated bibliography on the topic, and my website, "The Model Minority Stereotype Project" likewise, is the only dedicated webpage to the subject.

Scholars must read one another's work for ideas to proliferate, for scholars to coalesce, and for paradigms to shift. The more that I read emergent scholarship on the model minority myth (e.g., see Gin, Ho, Martinez, Murakami, \& Wu, 2017; Hsu, 2015; Phruksachart, 2016; Tran \& Curtin, 2017), and the more that I reflect upon the existing literature, I am left awestruck in how creative and advanced this scholarship has become. From my perspective, research that challenges the model minority myth is important because it continues to influence future possibilities.

This special issue, intentionally focused on Southeast Asian Americans and the model minority myth, is important because Southeast Asian Americans have been "politically invisible" (Wagner, 2016) and because although "an impressive number of Americans whose ancestors are from Cambodia, Laos, and Vietnam ("Southeast Asian Americans") have achieved tremendous success in education, a disproportionate number have found it difficult to succeed academically" (Yang, 2014, p. 51).

In 2015, I co-edited Killing the Model Minority Stereotype: Asian American Counterstories and Complicity with Bradley Porfilio. Part IV of the book highlighted considerations when conducting research on the model minority stereotype. Three chapters in this section of the book stand out in my mind: Grant Morgan and Kari Hodge's two chapters: "A Primer on Research

(a)

SORERIGHISRESERNEDR Readers are free to copy, display, and distribute this article, as long as the work is attributed to the author(s) and the Journal of Southeast Asian American Education \& Advancement, it is distributed for non-commercial purposes only, and no alteration or transformation is made in the work. More details of this Creative Commons license are available at http://creativecommons.org/licenses/by-nc-nd/3.0/. All other uses must be approved by the author(s) or JSAAEA.

Journal of Southeast Asian American Education \& Advancement, Vol. 12. Iss. 2. Special Issue (2017) ISSN: 2153-8999 
Validity for Conducting Quantitative Studies of the Model Minority Stereotype" and "Statistical Procedures for Addressing Research Fallacies Such as the Model Minority Stereotype" and Grant Morgan, Kari Hodge, and my chapter "An Asian American Subgroup Analysis of the RestrictedUse ELS: 2002 Dataset: Mixture Modeling as a Way to Problematize the Asian American 'Model Minority' Stereotype." These chapters, collectively, shared statistical and methodological considerations for combatting the deleterious stereotype, something existing scholarship hadn't explicitly done. The volume also centered what Wu (2016) mentioned in The Color of Success: that the field can be self-fulfilling in propping up - not problematizing - the stereotype.

Although Petersen was not really the sole progenitor of Asian Americans becoming America's model minorities, he is treated as such. This special issue commemorates the unofficial 50-year anniversary of the model minority stereotype, as measured by Petersen's (1966) New York Times Magazine publication. This special issue contains articles that add to model minority stereotype knowledge to be sure, but I also encourage readers of this issue to visit "The Model Minority Stereotype Project" (MMSP) ${ }^{2}$ webpage, which I curate, for more resources on the subject.

According to Wu (2016), "For Asian Americans, then, the challenge has become how to live beyond the model minority, how to navigate the world day to day without being constrained by such expectations" (p. 255). I would add, as other scholars have (e.g., see Poon, Squire, Kodama, Byrd, \& Chan, 2016), that while "opposing" the model minority stereotype is important, so too is identifying what it means to be an Asian American in a post-truth era marked by President Trump's incessant use of the term "fake news." The stakes are high for education in an era of disintegrating truths. It was Trump himself who said that he "loves the poorly educated." 3

Asian Americans are not passive people. The model minority stereotype didn't develop only because journalists made them out to be models or exemplars. Although the model minority stereotype is fake, it's been useful for those in power and even at times, some wealthier more privileged Asian Americans. The articles in this special issue are important, timely, and original. Collectively, the authors offer the field new material that can be used to propose and crystallize post-model minority futures for Asian Americans and society globally.

In closing, I'd like to publicly say that I am deeply appreciative of Dr. Wayne E. Wright who allowed me to guest edit this issue. Dr. Wright, it took a bit longer than planned, but thank you for your involvement in the process, and the support that it took to close out the project. Thanks go to Sung-ae Kim for typesetting the issue. I also would like to thank the reviewers who helped strengthen the articles. They are:

René Antrop-González, Ph.D. Metropolitan State University

Paul Spies, Ph.D. Metropolitan State University

Rachel Endo, Ph.D. University of Washington Tacoma

Christopher Vang, Ph.D. California State University, Stanislaus 
Vichet Chuuon, Ph.D.

University of Minnesota. Twin Cities

Gilbert Park, Ph.D.

Ball State University

Wayne E. Wright, Ph.D.

Purdue University

\section{Endnotes}

1. Searching Google Scholar "Success Story: Japanese American Style" indicates that this New York Times Magazine article has been cited 469 times.

2. The Model Minority Stereotype Project (MMSP) can be accessed at www.nicholashartlep.com

3. See Trump's Nevada speech here: https://www.youtube.com/watch?v=Vpdt7omPoa0

\section{References}

Gin, K. J., Ho, T., Martinez, D., Murakami, D., \& Wu, L. (2017). Revisiting the model minority myth in higher education. Journal of Student Affairs, 26, 13-20.

Hartlep, N. D. (2013). The model minority stereotype: Demystifying Asian American success. Charlotte, NC: Information Age.

Hartlep, N. D., Morgan, G. B., \& Hodge, K. J. (2015). An Asian American subgroup analysis of the restricted-use ELS: 2002 dataset: Mixture modeling as a way to problematize the Asian American "model minority" stereotype. In N. D. Hartlep \& B. J. Porfilio (Eds.), Killing the model minority stereotype: Asian American counterstories and complicity (pp. 357-380). Charlotte, NC: Information Age.

Hartlep, N. D., \& Porfilio, B. (Eds.). (2015). Killing the model minority stereotype: Asian American counterstories and complicity. Charlotte, NC: Information Age.

Hsu, M. Y. (2015). The good immigrants: How the yellow peril became the model minority. Princeton, NJ: Princeton University Press.

Morgan, G. B., \& Hodge, K. J. (2015). A primer on research validity for conducting quantitative studies of the model minority stereotype." In N. D. Hartlep \& B. J. Porfilio (Eds.), Killing the model minority stereotype: Asian American counterstories and complicity (pp. 293-210). Charlotte, NC: Information Age.

Morgan, G. B., \& Hodge, K. J. (2015). Statistical procedures for addressing research fallacies such as the model minority stereotype. In N. D. Hartlep \& B. J. Porfilio (Eds.), Killing the model minority stereotype: Asian American counterstories and complicity (pp. 311333). Charlotte, NC: Information Age.

Petersen, W. (1966). Success story: Japanese American style. New York Times Magazine.

Phruksachart, M. (2016). The Asian American next door: Enfiguring the model minority on the domestic melodrama. Amerasia Journal, 42(2), 96-117.

Poon, O., Squire, D., Kodama, C., Byrd, A., \& Chan, J. (2016). A critical review of the model 
minority myth in selected literature on Asian Americans and Pacific Islanders in higher education. Review of Educational Research, 86(2), 469-502.

Tran, J., \& Curtin, N. (2017). Not your model minority: Own-group activism among Asian Americans. Cultural Diversity and Ethnic Minority Psychology. Advance online publication. 1-9.

Wagner, A. (2016, September 12). Why are Asian Americans politically invisible? The Atlantic. Retrieved from https://www.theatlantic.com/politics/archive/2016/09/why-dont-asianscount/498893/

Wu, E. D. (2016). The color of success: Asian Americans and the origins of the model minority. Princeton, NJ: Princeton University Press.

Yang, K. (2014). Southeast Asian American children: Not the "model minority." In N. D. Hartlep (Ed.), The model minority stereotype reader: Critical and challenging readings for the 21st century (pp. 51-72). San Diego, CA: Cognella. 


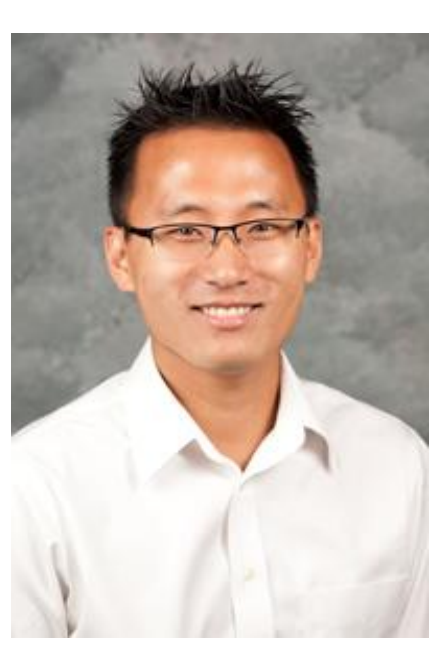

\section{About the Editor}

Nicholas D. Hartlep (Ph.D., University of Wisconsin, Milwaukee) is currently an Assistant Professor of Urban Education at Metropolitan State University, St. Paul, MN. In 2015 he received the University Research Initiative (URI) Award from Illinois State University and a Distinguished Young Alumni Award from Winona State University, which recognized him as a graduate who had distinguished himself in his work and community. In 2016 the University of WisconsinMilwaukee presented him with a Graduate of the Last Decade (GOLD) Award for his prolific amount of writing. Metropolitan State University presented him with the 2017 Community Engaged Scholarship Award for his practice of community-based teaching, learning, and research. Hartlep serves on the editorial boards of several journals and is lead editor of the "Urban Education Studies" book series with Information Age Publishing. His scholarly books include Going Public: Critical Race Theory \& Issues of Social Justice (2010), The Model Minority Stereotype: Demystifying Asian American Success (2013), Unhooking from Whiteness: The Key to Dismantling Racism in the United States (2013), The Model Minority Stereotype Reader: Critical and Challenging Readings for the 21st Century (2014), Killing the Model Minority Stereotype: Asian American Counterstories and Complicity (2015), The Assault on Communities of Color: Exploring the Realities of Race-Based Violence (2015 with Kenneth J. Fasching-Varner), Modern Societal Impacts of the Model Minority Stereotype (2015), Critical Storytelling in Uncritical Times: Stories Disclosed in a Cultural Foundations of Education Course (2015), and Asian/American Curricular Epistemicide: From Being Excluded to Becoming a Model Minority (2016 with Daisy Ball), and Pay to Play: Race and the Perils of the College Sports Industrial Complex (2017 with Lori L. Martin and Kenneth J. Fasching-Varner). He recently finished the edited book: The Neoliberal Agenda and the Student Debt Crisis in U.S. Higher Education: Voices of Students and Faculty (2017 with Lucille L. T. Eckrich and Brandon O. Hensley for Routledge). 


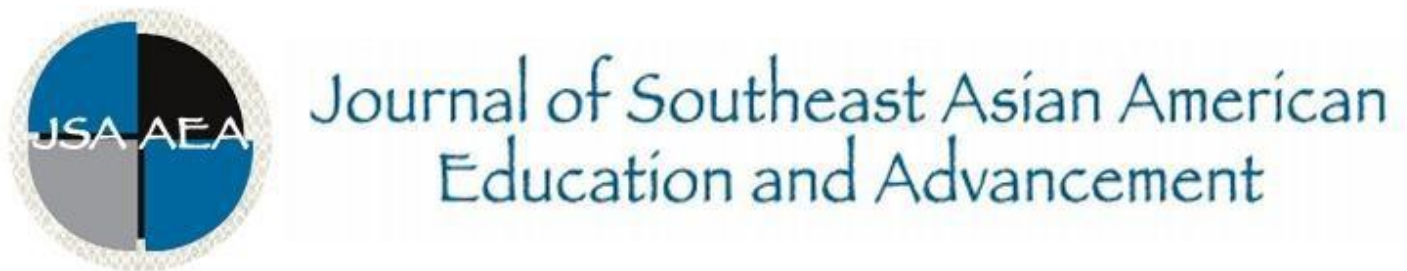

Vol. 12 Iss. 2 Special Issue (2017) www.JSAAEA.org

Special Issue Editor

Dr. Nicholas D. Hartlep

Metropolitan State University

Editor

Dr. Wayne E. Wright

Purdue University

Associate Editors

Dr. Chhany Sak-Humphry

University of Hawaii at Manoa

Dr. Phitsamay Sychitkokhong Uy

University of Massachusetts, Lowell

Book Review Editor

Dr. Vichet Chhuon

University of Minnesota

Creative Works Editor

Bryan Thao Worra Lao

Assistance Center

Journal Manager

Sung Ae Kim

Purdue University

\section{Editorial Review Board}

Dr. Steve Arounsack

California State University, Stanislaus

Dr. Sovicheth Boun

The State University of New York, Fredonia

Dr. George Chigas

University of Massachusetts, Lowell
Dr. Carl L. Bankston III

Tulane University

Dr. Angela Reyes

Hunter College, The City University of New York

Dr. Loan Dao

University of Massachusetts, Boston 


\author{
Dr. Hien Duc Do \\ San Jose State University \\ Dr. Sophal Ear \\ Occidental College \\ Dr. Virak Chan \\ University of Texas at San Antonio \\ Dr. Nancy H. Hornberger \\ University of Pennsylvania \\ Dr. Peter Nien-Chu Kiang \\ University of Massachusetts, Boston \\ Dr. Ha Lam \\ Eastern Mennonite University \\ Dr. Jonathan H. X. Lee \\ San Francisco State University \\ Dr. Monirith Ly \\ Royal University of Phnom Penh \\ Dr. Bic Ngo \\ University of Minnesota \\ Dr. Leakhena Nou \\ California State University, Long Beach \\ Dr. Mark Pfeifer \\ SUNY Institute of Technology \\ Dr. Loan T. Phan \\ University of New Hampshire \\ Dr. Kalyani Rai \\ University of Wisconsin, Milwaukee \\ Dr. Cathy J. Schlund-Vials \\ University of Connecticut, Storrs \\ Dr. Nancy J. Smith-Hefner \\ Boston University \\ Dr. Yer J. Thao \\ Portland State University \\ Dr. Monica M. Trieu \\ Purdue University \\ Dr. Silvy Un \\ Saint Paul Public Schools \\ Dr. Terrence G. Wiley \\ Center for Applied Linguistics
}

\author{
Dr. Changming Duan \\ University of Missouri, Kansas City \\ Dr. Sothy Eng \\ Lehigh University
}

Dr. Zha Blong Xiong

University of Minnesota

Dr. Peter Tan Keo

New York University

Dr. Kevin K. Kumashiro

University of San Francisco

Dr. Ravy Lao

California State University, Los Angeles

Dr. Stacey Lee

University of Wisconsin, Madison

Dr. Sue Needham

California State University, Dominguez Hills

Dr. Max Niedzwiecki

Daylight Consulting Group

Dr. Clara Park

California State University, Northridge

Dr. Giang Pham

University of Massachusetts

Dr. Karen Quintiliani

California State University, Long Beach

Dr. Phala Chea

Lowell Public Schools

Dr. Fay Shin

California State University, Long Beach

Dr. Christine Su

Ohio University

Dr. Alisia Tran

Arizona State University

Dr. Khatharya Um

University of California, Berkeley

Dr. Linda Trinh Vo

University of California, Irvine

Dr. Yang Sao Xiong

University of Wisconsin-Madison 


\section{Doctoral Student Editorial Review Board}

\author{
Anna H. Yang \\ University of Georgia \\ Annie BichLoan Duong \\ San Joaquin County Office of Education \\ Hoa Nha Nguyen \\ Boston College \\ Malaphone Phommasa \\ Marshall University \\ Molly Wiebie \\ The University of Texas at Austin
}

\author{
Dung Minh Mao \\ University of Minnesota \\ Thien-Huong Ninh \\ University of Southern California \\ Krissyvan Truong \\ Claremont Graduate University \\ Soua Xiong \\ San Diego State University \& Claremont \\ Graduate University
}

